\title{
DEVELOPMENT OF WAR AND ART OF WARFARE
}

\author{
Vancho Kenkov \\ Institute for security, defense and peace - Faculty of Philosophy, Skopje \\ vancok@fzf.ukim.edu.mk \\ $\&$ \\ Sergej Cvetkovski \\ Institute for security, defense and peace - Faculty of Philosophy, Skopje \\ sergej@fzf.ukim.edu.mk
}

\begin{abstract}
All segments of warfare, from antiquity until today, have gone through evolutionary change. The evolution is a result of many factors, but the most important ones include development of society, technological and technical development, achievements in science and art of war. The evolution of war and military skill is analyzed through centuries starting from slaveholder period until modern era. The paper outlines the basic features and importance of these factors, while particular attention is paid to modern conditions. Authors also try to make a parallel between constant development of war and changed significance of human and material-technical factor. The research question is whether development of war and changed role of factors of war are mutually conditioned processes. The rapid and comprehensive development of military equipment and technology is analyzed as well as its impact on the physiognomy of war and military skill, wherein it is highlighted that human as a factor of the war is gradually losing its dominant role which it traditionally had throughout the history of wars.
\end{abstract}

Key words: evolution of war, technical and technological development, factors of war, evolution, industrial revolution, mass strikes.

\section{Introduction}

War, as one of the most complex social phenomena, is about 10,000 old. Development of mankind was much more "history of wars" and much less "history of peace." 
As social phenomenon, the war affects all relevant factors essential to the condition and the development of society (global and local). The centers of power, prosperity, and peace shifted around in response to this process, producing new and more effective forms of governance, while driving social development to higher level. The great question that remains, though, is whether the long-run shape of the growth curve will be logisticflattening out when the entire planet is subsumed under a single government-or boomand-bust, leading to a catastrophic collapse (Morris 2012, 11). Social changes have been going hand by hand with the continuous changes in warfare. It is an ongoing process. But this relationship has always been two-way street.

\section{Main Features of War through History}

The evolution of war has to be approached dialectically i.e. with respect to the evolution of human society and vice versa. War was born in the transition towards the era of slavery, and its evolution ever since has followed the changes in society.

During the era of slavery waging war was a decision made by an individual who was at the same time a ruler and army commander. The wars were led for territorial conquest, slaves and loot. During early periods, the armies were not permanent, but later on a phase of slaveholder militia was introduced. The changes reached up to a mercenary army as a standing army, whose support, weapons and equipment was provided by the state. Characteristically, the land army was a major form of military organization and later on navy was established too (Naval Reserve Officers Training Corps 2015). In this era military formations such as Centurion, Phalanx, Manipulateur and Legion were most significant.

The battle ground was essentially natural setting, without man-made objects; military actions were mostly carried out on land and rarely at sea. System of separate battle and decisive battles prevailed, while the speed of movement was restricted since armies were moving on foot or on horseback. Armed struggle was influenced only by the climate (winter, summer, fall and spring) and meteorological factors (rain, fog, ice, etc.). Some distinguished military leaders and rulers contributed to development and perfection of the martial art. The most famous ones were Alexander the Great, Julius Caesar, Darius, Hannibal, Barca, Octavian Augustus, Scipio Africanus and others (Ratković 1981). The most important written papers on the art of warfare were drafted by Sun Tzu Woo in China and Thucydides in ancient Greece (ibid., 106-112). 
In feudal society military organization bore all characteristics of the society that was fragmented in economic, political and territorial terms. The military was small, insufficiently organized and fragmented. Feudal lords were often unable to resist the well organized armies led by Mongolian, Tartars, Turks and other invaders at the time. Only the emergence absolutist monarchies created preconditions for emergence of large mercenary armies that gradually turn into modern standing armies. By the 15th century primary weapons were the sword and spears, and at the end of that period appears the rifle (McGlynn 1994). From the 16th century artillery gets an important role in the armed struggle (Шиљеговић and Тодоровић 1971), and dominant forms of internal organization were infantry, cavalry, artillery and engineery. Feudalism did not see any significant social progress neither there was any significant progress in the military sphere. It was marked by regress in terms of military theory and military skills development.

In the period of industrial society warfare became more efficient: weaponsparticularly small arms-was easier to use, while states abandoned complete reliance on professional soldiers in favor of conscription. Conscription meant increase of the number of military personnel available for combat. This was vastly used by Napoleon Bonaparte. The changes in the formation and organization of the armed forces included new kinds and services. Technological advances became increasingly important; while the armies of the previous period had usually had similar weapons, the industrial age saw encounters (such as the Battle of Sadowa), where possession of a more advanced technology played a decisive role in the outcome. With the introduction of new and improved weapons the firepower gets a special place in the armed fight, which determined the focus tasks and accomplished goals of military actions. The battle deploys started to become more friable, broader and deeper and maneuver received prominence in the art of warfare because of increased mobility, speed and suddenness of actions.

Rapid, diverse and comprehensive technological and technological development was a major feature of capitalist society with several technological revolutions. The science reached major proportions and made the greatest contribution to social progress. The capitalist social order led to the greatest progress in the development of human society. It significantly influenced the development of military science, the military equipment, the armed forces and the military skill. Wars were fought for territories and spheres of influence, and the objectives were primarily economic. The Total war was child of industrial warfare too. William Tecumseh Sherman's "March to the Sea" and Philip Sheridan's burning of the Shenandoah Valley during the American Civil War and the strategic bombing of 
enemy cities and industrial factories during World War II are examples of total warfare. Total War, first and foremost called upon entire societies to gear up for a far-reaching struggle: "Materially it drew heavily upon an industrial nation's full range of resources, while ideologically it could not be a disinterested or distant affair from people's daily life: the whole of a nation was called upon to unite and commit to combating other whole nations. Organizationally, a state's government commandeered and coordinated much of the production, transportation, communications, and manpower capacity of the society, channeling it into the effective staffing, arming, moving, and re-supplying of an enormous fighting force that ran through people and materiel at a tremendous rate" (Lynch \& Bravman 2008).

All that influenced the role of the individual in war. He was and still is engine of all military events: he decided on going in to the war, he was the carrier of the military production and services and he was also participant in combat operations.

All of aforementioned changes secured a special place for science, while the education of professional military staff has become a requirement for successfully conduction of the tasks of the armed forces in peace and war. The war become more complex and richer in its content and it covers all the structures of society and all social activities and institutions. As war became subject of interest of many sciences, the art of warfare and military science has intensively and comprehensively developed. Achievement of success in war became dependent on use of scientific achievements, because apart from warfare skill, the military officers are required knowledge and the use of achievements of the military as well as other sciences. Successful management and command today assumed knowledge and appreciation of the action of scientific logic and the laws of armed struggle and war.

\section{Importance of Art of Warfare and its Development}

Development of art of war is predominantly conditioned by the constant changes in armament and gradual (downward) change of the role of the human as factor of war. The recent concept of Revolution in Military Affairs (RMA) is even somewhat vague and changeable concept that has had many different interpretations which attempt to explain how warfare has been shaped by emerging technologies (Chapman 2003). It highlights the short outbursts of rapid change followed by periods of relative stability. The art of warfare is still rapidly evolving. The new weapons and military equipment determine the process of perfection of art of warfare. This process takes place in three main directions: a) finding 
solutions for comprehensive and rapid exploitation of the effects and results of the action of modern weapons (the latest technological generations); b) solving the problems of defense and protection of these weapons, and c) in parallel with this, the integration of art of warfare with the necessary elements of propaganda, the political, the economic, the informational and other contents of the war, which role is increasingly important for the process and the outcome of the war.

The armed forces of the great powers have put the focus of improvement of art of warfare on use of the military actions that allow larger effect of modern weapons with minimum (human) losses on their own side. For that purpose, special attention is given to long distance activities i.e., airspace and outer space. In parallel to their interests and activities primarily on land, those powers seek for allies and use their services and also use the forces that already exist on the territory of the opponent as various military formations, separatist and other organizations and groups, as well elements that are prone to them. They also engage force for propaganda, political, psychological, economic and other activities and actions.

In contrast, the armed forces of mid-sized, and especially of small states, put theit focus on finding solutions to counter the technical superior opponent. Their military skill is sort of a combination of defense and protection of high-tech weapons, as well as initiatives, shrewdness, and superior training of all types of forces for pairing technically superior and stronger opponent, with maximum reliance on its own strengths, potentials and opportunities. The measures of anti-aircraft, anti-electronic protection, augmentation of propaganda, psychological and intelligence action and decisive counter-terrorist activities have great importance for the defense of small states. They are likely to avoid direct military confrontation and instead resort to some form of "asymmetric" warfare, including terrorism and guerrilla combat. These forms of warfare will have disastrous consequences for civilians, as they already have (Chapman 2003, 18).

\section{The Role of the Factors of Warfare}

The technological and scientific development, the invention and use of new types of weapons contributed some factors of armed struggle to gain a new dimension. Analyzing the wars in the last 20 years, we can conclude that the factors of military struggle (the human, the material and technical resources, the time and the space), have got changed roles. In modern war, the main factors of armed struggle are human and military equipment, while the space and time lose their significance. However, they act 
simultaneously and have mixed effect. Although the new weapons, modern military equipment, increased efficiency and the destructive power of weapons take up an increasingly important role, the role of the human factor although gradually losing its importance that have had in the past, still remains significant (Mikić 2003, 173).

Anything built by man can be destroyed by man. The humans decide on all important issues related to war and use of force, apply most contemporary armaments and use it appropriate of its intentions and goals. Even in contemporary warfare they retain the functions that had in previous wars. Modern war today requires contemporary soldier with great knowledge and ability. About the characteristics of such a soldier, the Alvin and Heidi Toffler have said that modern soldier is not only ammunition carrier mule: "He knows mechanized and infantry tactics. He is trained to work together in operations with helicopters and aircrafts, mostly because he guides them. Guiding the planes means that he also knows the opponent weapon. He is adept at geometry and navigation. He manages mortars and artillery, armored and anti-armored weapons, mine and counter mine weapons and tactics, use of explosives, computers, motor vehicles, laser designators, thermal surveillance tools, and devices for satellite communications" (Toffler 1998, 85) as part of its equipment. Among other things, he manages the organization of supply and the wider logistics. Actually, the man as only living factor in warfare. So, overall moral and professional military values are features that put man on the center spot and still make him a decisive factor in armed struggle (Giap V. Nguyen 1970, 247).

Scientific and technological developments, especially in terms of military equipment, have influenced continuous increase of the role of material and technical factor in modern war. The growing power of arms is manifested in the growing effect of the infliction of loss and destruction of the premises. The development aims at increase of armaments firepower, its precision, the speed of the various activities and the effects on the target. This particularly applies to the role of electronics, missile and informatics technology (Chapman 2003, 10). Use of modern weapons requires hiring fewer military personnel but also requires more skilled and highly educated officers. The role of high educated cadres has been pointed by Alvin and Heidi Toffler in "War and Anti-War"; they argue that in the 1991 Gulf War, the US sent 500 of thousands of troops, 200 thousand soldiers there were for logistical support while the victory was won by 2000 soldiers who used most sophisticated weapons and equipment (in Toffler 1998, 86). However, it must not be left out the perspective that war goes in the direction of full automation. One of the reasons is the desire to minimize the risk to friendly forces. Computer technology and robotics 
increasingly aspire to take the priority place of the human factor in the hostilities conduction and war in general. "The development of new technologies of warfare, including autonomous weapons or "killer robots" and cyber warfare, raised fundamental concerns about the acceptability of allowing machines to independently take life-and-death decisions" (United Nations 2014).

Special features of modern wars are the actions of the armed forces at great distances and heights. Considering the technical capabilities of modern weapons, overcoming the space is faster and easier. The territory, the relief and the hydrographic elements in modern war took on new meaning and role. They certainly continue to affect and constitute a requirement for military operations, but their impact, compared to the previous periods is less. The aviation, helicopters and satellites allow mastering space without the influence of man-made and natural obstacles and do not represent any difficulty. Taking into account the use of modern weapon systems as cruise missiles, intercontinental missiles, satellite guided smart bombs and missiles that are launched with hundreds of kilometers away from the desired goal when there is no any established direct contact between opponents, it is obvious that space as a factor in armed struggle gets changed role of its meaning. With usage of these weapons systems and equipment is avoiding losses in manpower, while with strong, precise and massive strikes are being achieved the desired effects. Of course, today only great powers have the most advanced weapons systems and equipment and that is what makes them still superior to all others. Anyway, the military technology is a game of haves, have-nots and catch-ups.

The relation between human factor and technology is very interesting one. The policy of great powers leans away from using its troops in the hot spots. With the technology at its own disposal the state at war finds it better to rely on troops from 'other nations' because they are more expendable and their death would not cause such a domestic public uproar. In addition if the troops did atrocities to a number of military and civil enemies for whatever reason, again the country at war would be free of blame.

Time factor as well as other factors of warfare has changed in terms of its role and meaning too. Modern weapons systems and command systems have much reduced time limits or have shorten the time for combat actions preparation, for the operation of the controls, decision-making and logistical tasks, by reducing the time limitations. The largest contribution in this regard had modern technology, technique (especially informatics), and the features and capabilities of armament. Here, stems the increased importance of education and training of staff, particularly managers and the specialists who handle 
modern equipment, because of the need to quickly and efficiently perform the operational tasks in short time and during intensive hostilities.

Regarding the importance clime and meteorological factors, it has also undergone some changes. Modern weapons systems are less dependent on these elements. The modern aviation is equipped with adequate instruments and devices to perform its combat activities in all weather conditions. The missile weapons systems, the laser and especially satellite guided ones are the least dependent on weather conditions too.

\section{Predictions about the Future Wars}

The following thoughts seem too theoretical but they are also being inspired by the current technological trends. Nations do not go through technological regress; soon many of them will use spy satellites and cruise missiles. By 2020 robotic, nanotechnology, and genetic weapons will probably dominate advanced war fighting, and anti-missile systems may have made the old style of nuclear bullying obsolete. (Morris 2012, 33)

Once we move into space it will be easier to destroy such satellites. Without pinpoint accuracy available from spy satellites, forces will have to resort to other means to gather information. Small teams will probably have to be sent in to find targets for the cruise missiles. Stealth will be their best defense. It has come to the point that if a target can be seen it can be destroyed. As warfare moves into space a great many things can change. If a ground based unit can attack a space craft then it would be unlikely a space craft will enter orbit until it is safe. On the other hand, once a craft controls orbit it will be able to destroy targets on the ground with pinpoint accuracy.

One cannot predict the way wars will be fought in the future. With the growing number of weapons of mass destruction one can assume that to avoid the attention of these weapons combat units will be smaller, faster and more evasive. They will not assemble for mass destruction and they will try to avoid detection by the enemy whenever is possible. What is quite certain about the wars in the near future is that the ongoing researches for the needs of war in the next 15 years are focused on enhanced implementation of robotics, bioengineering, artificial intelligence and nanotechnology (Busnell 2001).

\section{Instead of Conclusion}

Until the beginning of the 20-th century, the soldiers were fighting in big formations where commanders could re-group the troops in the way they could inflict most 
damage to the enemy. In modern times, the war has evolved from a traditional activity in to a scientific enterprise where success is valued above methods. The notion of total war is the extreme of this trend. Militaries have developed technological advances rivaling the scientific accomplishments of any other field of study. As in the years around 1900, a revolution in military affairs is underway. Units to avoid high casualties started using dispersed formations. With the development of the atomic bomb, the large militaries again realized the vulnerability of concentrating their armies like they once did. Radios made it easier to call for fire support and with increased reliability while the expense of radios goes down and the usage of radios will be more than ever before. One level further was application of satellites for need of warfare. From the Allied point of view The Desert Storm was one side fight for Allied ground forces. The allies decimated the Iraqi ranks and infrastructure from the air and sea before the troops ever entered the scene.

What distinguishes modern military organizations from those previous is not their willingness to prevail in conflict by any method, but rather the technological variety of assets and methods available to modern battlefield commanders. Technology has changed the way war is fought to an incredible extent. With current advances in technology it could change even more. The cruise missile, which can strike with pinpoint precision, is now more important than ever. Technology is becoming more precise and lethal. Already, unmanned aircraft are employed by some forces. Unmanned craft it is smaller and it is less restricted by high gravity forces and can probably fight better than a manned aircraft. One should always have in mind that every system has a weakness and strength. Military policy has been, and will likely always be to minimize the strengths of its equipment and minimize the weaknesses.

It is fair to say that the qualitative revolutions in the technology of target acquisition and destruction when coupled with the qualitative revolution in the manner in which wars must be fought on the modern battlefield combine to produce a style of warfare that is itself qualitatively different from almost all war that has gone before. With the human factor as still as primary factor of armed struggle, the challenging task for the modern officer is how to master these new circumstances (Richard and Metz 1992, 104).

It is unlikely that the military will regress... but, as Morris clearly point out that the evolution of war across the last fifteen thousand years has shifted incentives so much that traditional kinds of productive war have become unthinkable. Since the fall of the Soviet Empire, interstate war has almost disappeared, except for the occasions when the USA itself decided to wage it. Mass killing now happens almost entirely within failed states or 
when they export it in the forms of terrorism and civil war. The global rate of violent death has fallen well under 1 percent, far and away the lowest in history. One conclusion we might draw from the evolution of war is that productive war will continue mutating in the twentyfirst century, shifting incentives further toward peace, until at some point virtually no circumstances will remain in which violence seems profitable. At that point, the dream of a world without war will become a reality. The other, possible future is that we may be reaching a point at which productive war flips over into counterproductive war on a scale to dwarf anything the world has seen before. Either way, the next fifty years will be the most important in human history.

\section{Bibliography:}

1. Bushnell, M.Dennis. 2001. „Future Strategic Issues/Future Warfare [Circa 2025] ". Presented at 4th Annual Testing and Training Symposium and Exhibition: A National Partnership, National Defense Industrial Association, Orlando, August 1416.

2. Chapman Gary. 2003. An introduction to the Revolution in Military Affairs. Paper presented at the XV Amaldi Conference on Problems in Global Security, Finland, Helsinki, September.

3. Ciap Vo Nguyen. 1970. The military Art of People's War. Edited by Russel Stetler. New York: Montly review press.

4. Lynch Wendy and Bill Bravman. 2008. „Modern Warfare: An Overview for World History Teachers". In World History Connected. Vol. 2 No.2. Board of Trustees of the University of Illinois. Accessed 25. Nov. 2015.

http://worldhistoryconnected.press.illinois.edu/2.2/bravman.html

5. McGlynn, Sean. 1994. "The Myths of Medieval Warfare". In History Today. Vol.44 no 1. Accessed November, 25 20015: http://deremilitari.org/2013/06/the-myths-ofmedieval-warfare/

6. Mikić, Slobodan. 2011. "Naučne zakonitosti oružane borbe kao teorijski konstrukt vojnih nauka". Vojno delo Vol 63:83-95

7. Mikić, B Slobodan. 2003. Pogled na rat. Beograd: VIZ.

8. Morris, Ian. 2012. „Evolution of War". Cliodynamics Vol. 3: Iss. 1

9. Naval Reserve Officers Training Corps, "Evolution of warfare. Vol1", Accessed novemeber, 23, 2015. http://www.au.af.mil/au/awc/awcgate/nrotc/eow1.pdf

10. Ratković, Borislav. 1981. Vojni leksikon. Beograd: Vojnoizdavački zavod 


\section{Securiaty}

11. Richard A. Gabriel, Karen Metz. 1992. "A Short History of War: The Evolution of Warfare and Weapons". Professional Readings in Military Strategy Number 5. Army War College Carlisle Barracks: Strategic Studies Institute

12. Toffler, Alvin, and Hajdi Toffler. 1998. Rat i Antirat. Beograd: Paidea

13. United nations.2014. Meeting coverage and press releases. GA/DIS/3502

14. Wager, H. Halleck. 1861. Elements of Military arts and science. Bedfort: Applewood Books.

15. Шиљеговић, Бошко, и Војо Тодоровић. 1971.Војна енциклопедија, Вол. 7. Београд: ВИЗ. 